\title{
ENERGETIC AND SPATIAL CONSTRAINTS OF ARTERIAL NETWORKS
}

\author{
SANDRO ROSSITTI*
}

SUMMARY - The principle of minimum work (PMW) is a parametric optimization model for the growth and adaptation of arterial trees. A balance between energy dissipation due to frictional resistance of laminar flow (shear stress) and the minimum volume of the blood and vessel wall tissue is achieved when the vessel radii are adjusted to the cube root of the volumetric flow. The PMW is known to apply over several magnitudes of vessel calibers, and in many different organs, including the brain, in humans and in animals. Animal studies suggest that blood flow in arteries is approximately proportional to the cube of the vessel radius, and that arteries alter their caliber in response to sustained changes of blood flow according to PMW. Remodelling of the retinal arteriolar network to long-term changes in blood flow was observed in humans. Remodelling of whole arterial networks occurs in the form of increase or diminishing of vessel calibers. Shear stress induced endothelial mediation seems to be the regulating mechanism for the maintenance of this optimum blood flow/vessel diameter relation. Arterial trees are also expected to be nearly space filing. The vascular system is constructed in such a way that, while blood vessels occupy only a small percentage of the body volume leaving the bulk to tissue, they also crisscross organs so tightly that every point in the tissue lies on the boundary between an artery and a vein. This review describes how the energetic optimum principle for least energy cost for blood flow is also compatible with the spatial constraints of arterial networks according to concepts derived from fractal geometry.

KEY WORDS - blood vessels, cerebral arteries, fractals, hemodynamics, optimality concepts, retinal arteries, shear stress, vasodilation.

\section{Optimação energética e espacial de redes arteriais}

RESUMO - Aneurismas intracranianos e vasculopatia de hiperperfusão em pacientes com malformaçðes arteriovenosas cerebrais resultam do elevado stress hemodinâmico na rede arterial cerebral. $O$ estabelecimento de uma norma para a geometria arterial cerebral deve resultar em melhores critérios preventivos e de planejamento terapêutico para essas patologias. Uma rede arterial deve distribuir-se no espaço para todo o órgão perfundido, e ao mesmo tempo possibilitar a perfusão tecidual com adequado custo energético e mínimo stress hemodinâmico. O custo total do fluxo sangüíneo é a soma do custo $\mathrm{P}_{\mathrm{f}}$ para propulsāo do sangue através dos vasos (que aumenta com a redução do calibre das artérias) e do custo metabólico $P_{m}$ do tecido sangüíneo e dos vasos (que diminui com a redução do calibre das artérias). O equilibrio entre $\mathrm{P}_{\mathrm{f}}$ e $\mathrm{P}_{\mathrm{m}}^{\mathrm{m}}$ resulta no mínimo custo total quando artérias de grande e pequeno calibre organizam-se em uma hierarquia de ramificações tal que o raio interno do vaso $e$ proporcional ao cubo do fluxo sangiíneo (princípio do trabalho mínimo), o que significa que em cada ramificação arterial o raio do tronco $\left(r_{0}\right)$ e dos ramos $\left(r_{1}\right.$ e $\left.r_{2}\right)$ estão relacionados de acordo com a regra

$$
r_{0}{ }^{3}=r_{1}{ }^{3}+r_{2}{ }^{3}
$$

Oexponente de bifurcação " $n$ ", definido

$$
r_{0}{ }^{n}=r_{1}{ }^{n}+r_{2}{ }^{n}
$$

assume em condição ótima o valor 3 . A regra $n=3$ é também compatível à optimaçăo espacial de redes arteriais de acordo com princípios de geometria fractal. O exponente de bifurcaçāo aproxima-se desse valor em redes

This article is based on lecture notes of communications at the 7th Biomechanics Seminar (Göteborg, Sweden, April 22-23, 1993), at the 2nd International Conference on Stroke of the World Federation of Neurology (Geneva, Switzerland, May 12-15, 1993) and at the 8th International Symposium on Vascular Neuroeffector Mechanisms (Alberta, Canada, August 1-4, 1994). * From the Department of Clinical Neurosciences, Section of Neurosurgery, Göteborg University, Göteborg, Sweden. Aceite: 3-outubro-1994. 
arteriais de diversas espécies de mamíferos e nas artérias cerebrais humanas. Arteriolas retinianas reorganizamse após atrofia óptica (quando o fluxo sangǘneo retiniano diminui) de acordo com essa regra. Estudos experimentais in vivo e in vitro corroboram esse princípio. O controle do calibre arterial ocorre através de mediaçāo endotelial, com a produçāo de vasomediadores e alteraçōes da polaridade das membranas celulares, desse modo controlando o tônus vascular em curtos intervalos de tempo, e resultando em remodelaçāo anatômica a longo prazo.

PALAVRAS-CHAVE - artérias cerebrais, artérias retinianas, fluxo sangüíneo, geometria fractal, hemodinâmica, mecanismos de controle, vasodilatação, vasos sangüíneos.

The development of intracranial saccular aneurysms, the progressive remodeling of the cerebral vascular network in the presence of an arteriovenous malformation and the reversion of these changes after removal of the malformation are hemodynamically induced processes. Intracranial saccular aneurysms are generally accepted to be degenerative vascular lesions induced by locally increased wall shear stress with consequent lesion of the vessel wall at the apex, or flow divider, of the bifurcations ${ }^{15,35,37,42-44}$. The key factor for aneurysm formation is disruption of the internal elastic lamina $a^{42,43}$, but the degenerative process is thought to be initiated at the endothelial cell layer ${ }^{15}$. Aging, arterial hypertension, deficiency of type III collagen and other known risk conditions for aneurysm ${ }^{29}$, seem to be aggravating rather than causal factors ${ }^{43}$. As aneurysms arise at the apex of arterial bifurcations, the development of aneurysms is probably related to branching characteristics of the cerebral arteries that increase locally the hemodynamic stress ${ }^{37}$. Locally increased wall shear stress with consequent disruption of the endothelium and internal elastic lamina at the apex, or flow divider, of the bifurcations is probably the mechanism of aneurysm formation ${ }^{35,43,44}$. Changes in the shape of the arterial bifurcations during the cardiac cycle, resulting in loss of static equilibrium at the bifurcation apex and disruption of the vessel wall elements, have beem proposed as the mechanism of the aneurysm formation ${ }^{6}$. The role of other hemodynamic forces, such as stagnation pressure due to deceleration of the impinging blood stream and vibrations of the vessel wall induced by high flow rates, is at present uncertain ${ }^{43,44}$. High blood flow conditions in localized portions of the cerebral arterial network associated to higher incidence of saccular aneurysms are related to anatomical variations of the circle of Willis, ligature of vessels (e.g. ligature of the carotid artery in the neck) and arteriovenous malformations ${ }^{1,17.28,43}$. Increased hemodynamic stress might also be responsible for the progressive remodeling of the cerebral vascular network in the presence of an arteriovenous malformation, by the development of the so-called high-flow angiopathy ${ }^{30}$ and by the reversion of these changes after removal of the malformation ${ }^{13,27}$. Establishing a norm for the arterial circulation has potential implications for understanding such phenomena ${ }^{34}$.

The structure of arterial networks is constrained by energetic and spatial requirements. The optimum energy cost for blood transport is achieved at an equilibrium between the pump cost required to overcome viscous power losses, which decreases as the diameter of the vessels increases, and the metabolic (volume) cost for maintenance of blood and vessel wall tissue, which decreases as the diameter of the vessels decreases. The vascular system is also constructed in such a way that, while blood vessels occupy only a small percentage of the body volume leaving the bulk to tissue, they also crisscross organs tightly in order to maximize the surface area of the transfer regions. Thus the arterial system may be defined as a nearly space filing network of pipes arranged in series and linking remotely distributed transfer regions, such that a few large pipes carry blood across large distances rapidly and many short small pipes slowly distribute blood at the transfer regions. This article aims to summarize evidence that such a model is theorically possible, and that it corresponds to actual arterial networks with appreciable accuracy. The discussion is mostly based on the author's research on cerebral and retinal vessels of $\operatorname{man}^{31-39}$, but the results are surely applicable to other arterial trees. 


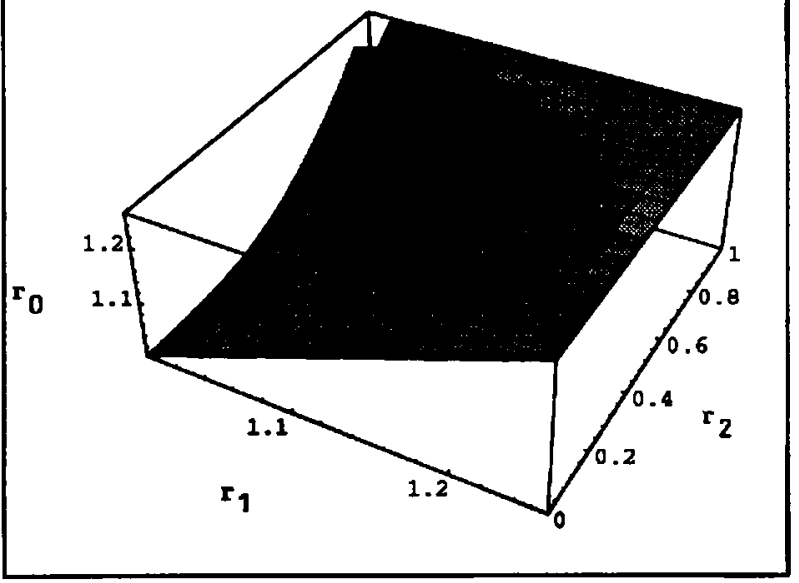

Fig 1. Relation between the radius of a parent artery and the radii of its branches in a vascular network constructed according to the PMW is plotted in this figure. The area ratio of the bifurcations, defined as

$$
\left[r_{1}{ }^{2}+r_{2}{ }^{2}\right] \cdot r_{0}^{-2}
$$

varies between $2^{1 / 3}$ in the case of a symmetrical bifurcation, and approximates 1.0 in the case of a very small branch from the main trunk.

$$
r_{0}^{n}=r_{1}^{n}+r_{2}^{n}
$$

\section{THE ENERGETICALLY OPTIMUM CONSTRUCTION OF ARTERIAL NETWORKS}

Optimization in physiology requires strongly simplified models. Mathematical modelling assuming Poiseuille flow in arteries indicates that an equilibrium between the pump cost and the volume cost is achieved when the arteries are arranged in a branching hierarchy such that the vessel radius ( $r$ ) is adjusted to the cube root of the volumetric flow (f), or:

$$
\mathrm{f}=k \mathrm{r}^{3}
$$

where $k$ is a constant involving the dynamic blood viscosity $(\eta)$ and the metabolic cost for maintenance of the blood and vessel wall tissue 16,23,33,34,40. An indirect measure of the division of flow at branching points is the junction exponent " $n$ " defined

where the indices 0,1 and 2 refer respectively to the parent artery and its branches. The energetical optimum occurs when $n=3$, i.e. at branching points we have

$$
r_{0}^{3}=r_{1}^{3}+r_{2}^{3}
$$

Thus the optimum rule for connection of narrow and wide arteries is that at branching points the radius of a parent artery is equal to the sum of the cubes of its branches. Such a rule is known as the principle of minimum work (PMW), and was proposed by Cecil D. Murray ${ }^{23}$. See Figure 1. The PMW was during several decades considered only of theoretical interest because it was falsified when applied to the parametric optimization of branch angles ${ }^{24}$. However, Murray's work concerned primarily vascular caliber, and the PMW was reconsidered when the parametric optimization of branch angles was proved irrelevant in terms of energy cost ${ }^{49}$. The PMW applies to arteries with $r>$ $500 \mu \mathrm{m}$, where blood behaves approximately as a Newtonian fluid and the dynamic blood viscosity is constant for the sake of our calculations, excluding the aorta. As mentioned above, the PMW assumes that the blood flow in arteries is steady and laminar. Further analysis by Uylings ${ }^{45}$ and by Mayrovitz ${ }^{21}$ have extended the principle of minimum work to all types of steady flow. See Figures 2 and 3. Rossitti ${ }^{31}$ proposed that in arterioles $(\mathrm{r}<500 \mu \mathrm{m})$ the vessel caliber/blood flow relation is to be corrected for the blood viscosity because of the Fahraeus-Lindquist effect, i.e. for arterioles the relation is:

$$
\mathrm{f}=k^{\prime} \mathrm{r}^{3} \eta_{\mathrm{rel}}^{-0.5}
$$

where $k^{\prime}$ is a constant and $\eta_{\text {rel }}$ is the relative apparent blood viscosity corrected for the vessel radius; data on the retinal arterioles ${ }^{33}$ seem to corroborate this hypotesis.

Despite its simplicity, the PMW appears to be a robust model for the growth and adaptation of arterial networks. The junction exponent is just less than 3 over several magnitudes of vessel caliber 


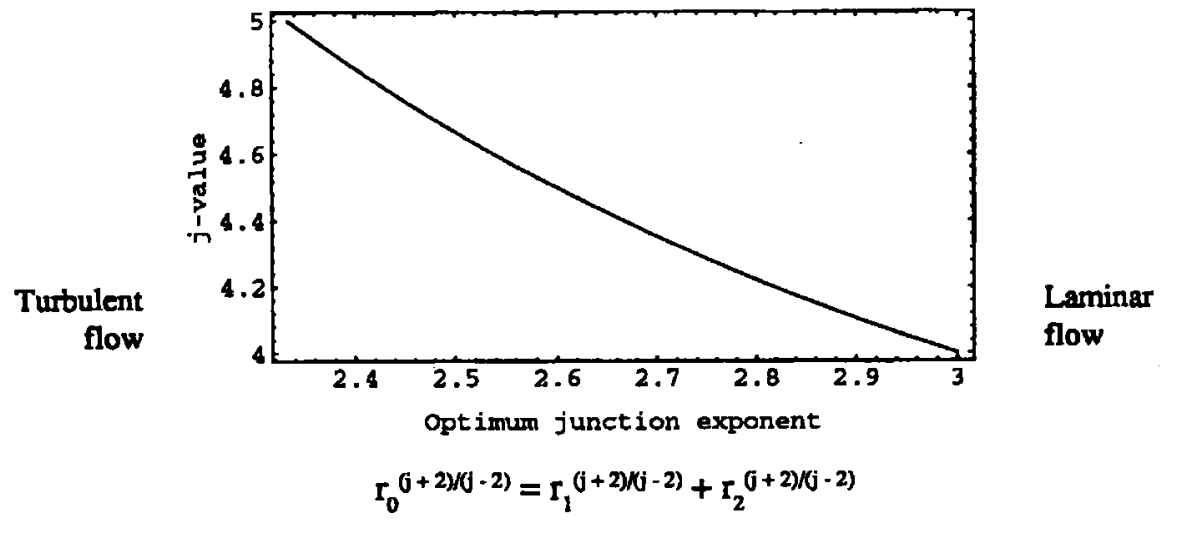

Fig 2. The PMW was developed assuming that the blood flow in arteries is steady and laminar. Further analysis has generalized the principle of minimum work to all types of steady flow, permiting to model the dimensional optimization of arteries when blood flow departs from laminar. For details please see the original article by Uylings". The optimum junction exponent is determined by the termj, which depends on the Reynolds number and assumes values between four (laminar flow) and five (turbulent flow). Most arterial trees have junction exponents in average approaching 3 with frequency distribution somewhat skewed to the right (se also Figure 5). Large arteries have junction exponents closer to 2 than to 3, suggesting that they are rather optimized to disturbed laminar flow. The plot shows the relation between the velocity profile paramenter $j$ and the required junction exponent for optimum arterial caliber/blood flow condition according to Uyling's equation.
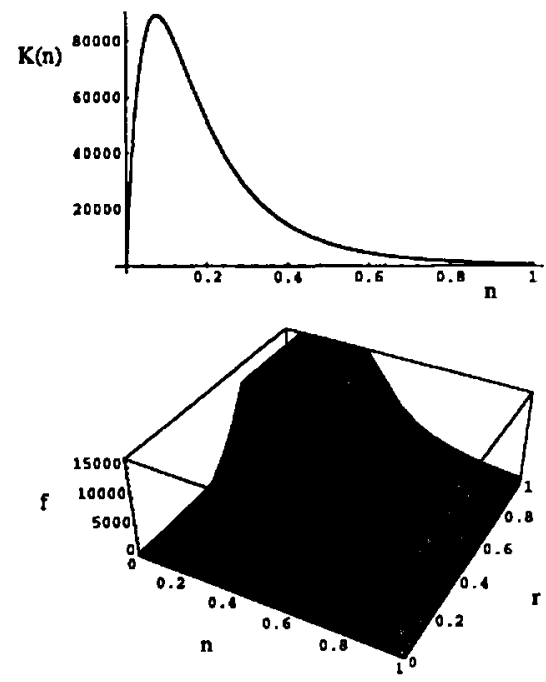

$\mathbf{f}=\mathbf{K}(\mathbf{n}) \mathbf{r}$

with $K(n)$ given by

$K(n)=[\pi /(3 n+1)]\left[n\left(K_{b}+2 \text { e } K_{J}\right) / K_{f}\right]^{1 /(n+1)}$

in corrosion casts or radiographs after contrast perfusion of diverse portions of the arterial tree of the human and other mammals ${ }^{16,40,47}$, as well as in the cerebral arteries of the living $\operatorname{man}^{34,36 .}$ See Figures 4 and 5. Remodelling of one and the same arteriolar network to long-term changes in blood flow provoked by descending optic atrophy was observed to occur according to the PMW in human retinal arterioles ${ }^{33}$. It is interesting to note that similar junction exponent laws have been found also in biological

Fig 3. Mayrovitz" showed that the third power dependence of flow on vessel radius defined in the $P M W$ (i.e. $f=\mathrm{kr}^{3}$ ) also holds for non-newtonian flow, but that the value of the constant $\mathrm{k}$ is altered. The flow-radius equation for microvessels proposed by Mayrovitz (i.e. $f=K(n) r^{3}$ ) contains the parabolic $(n=1)$ and plug-like flat $(n=0)$ velocity profiles as special cases. The plots of this equation presented in this figure were done with numerical values for blood viscosity $(K p)$, cost functions for blood volume $(\mathrm{Kb})$, vessel wall volume $(\mathrm{KW})$ and vessel wall thickness (e) taken from the literature ${ }^{21,22}$. The value obtained for $K(n)$ corresponding to laminar flow $(n=1)$ is $789.59 \mathrm{~s}^{-1}$. 
branching duct systems such as the large airways of the lungs, the branching of trees, the diffusion system of insects and duct systems of several species of sponge stromatoporoids, even in fossiles ${ }^{16,45}$.

It is reasonable to consider that regulation of arterial caliber in order to follow this rule is achieved locally at each vessel segment by mediation of some physical force. The above theoretical background assumed blood flow-induced shear stress to be this physical force ${ }^{24,11,16,22,23,25,32,34,40,41}$. Shear stress is expected to have the same magnitude over a wide range of branch generations in a vascular network obeying this principle, because flow rate influences shear stress proportionally to the third power of the vessel radius. The PMW implies strict functional relations between volumetric flow, flow velocity and vessel radius. Local changes of flow rate or in volume of the vascular system propagate upstream-downstream, and arteries alter their internal diameters in response to sustained changes of blood flow so that wall shear stress is kept under optimum limits. Empirical evidence corroborating this theory was obtained in animal studies showing that blood flow in arteries is approximately proportional to the cube of the vessel radius, and that arteries alter their caliber in response to sustained changes of blood flow ${ }^{19,22,33,41}$. These studies suggest that development and maintenance of optimum arterial caliber results of the interaction between the blood stream (shear stress) and the vascular endothelium. Arterial trees also seem to pursue optimum local conditions in terms of flow orderliness at bifurcation points, in this way minimizing the shear stress at the apex of the arterial bifurcations $\mathrm{s}^{35}$. Shear stress influences endothelial cell ultrastructure, shape, orientation and proliferation, modulates voltage changes across the cell membrane, alters ionic flow and intracellular $\mathrm{pH}$ and induces release of vasoactive substances ${ }^{25,32.46}$. However, any correlation between shear stress of the blood stream with stresses and strains inside the endothelial cell is presently obscure ${ }^{9}$. Theoretical considerations of this problem may lead to contradictory conclusions if in the

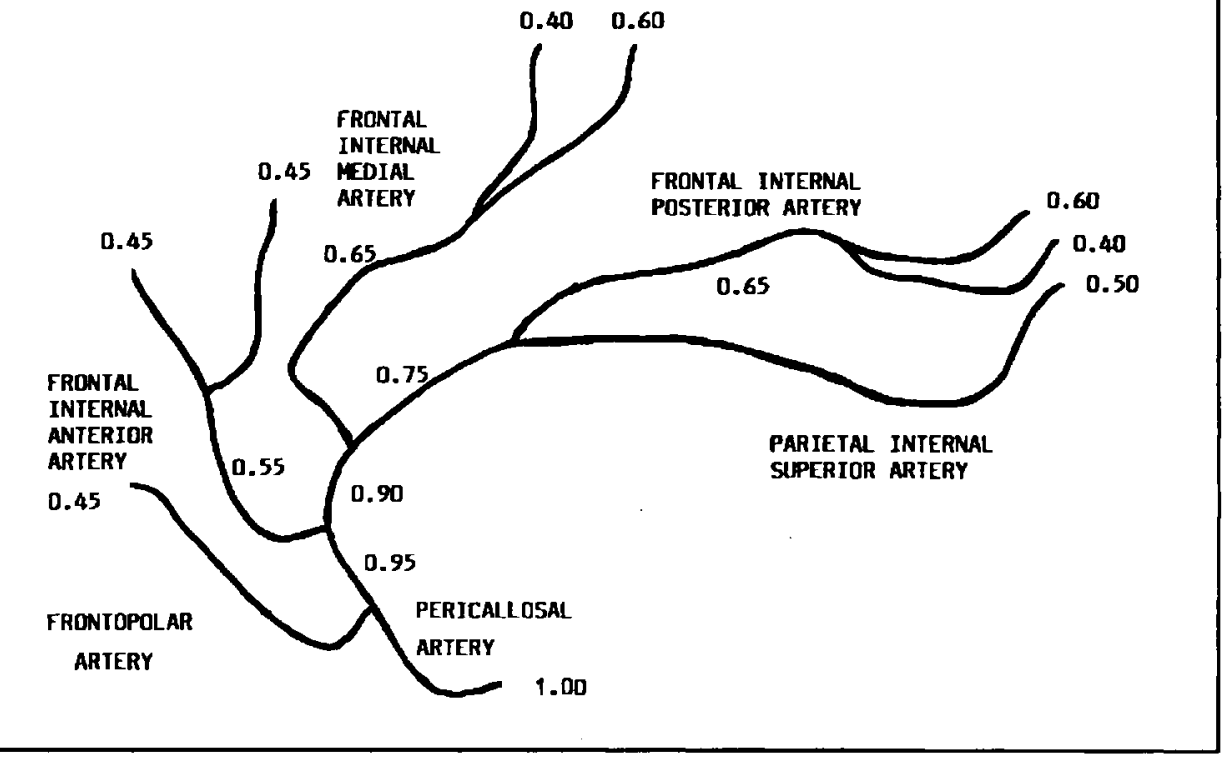

Fig 4. The relation $r_{0}{ }^{3} \approx \Sigma r_{n}^{3}$ is valid for a given segment of the arterial tree distal to a given point. This figure shows seven branch points of the anterior cerebral artery system in a cerebral angiography considered normal (the subject was a woman aged 32 years). Note that the cube of the radius of the pericallosal artery $(1.00)$ is approximately the sum of the cubes of the radii of all distal branches (0.96). This arterial tree was analyzed in detail by Rossitti and Löfgren (Biomech Sem 1993, 7: 21-26). The junction exponent was in average 2.98 including the branching of the middle cerebral artery ${ }^{36}$. 


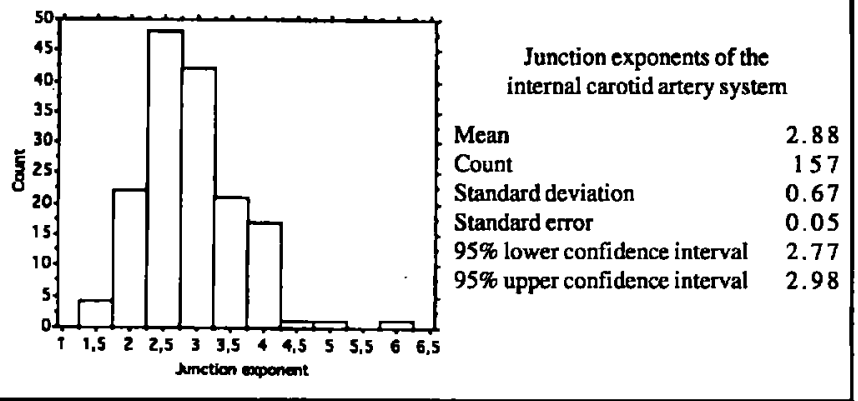

Fig 5. The frequency distribution of junction exponents in four branch generations of the internal carotid artery system in man $(N=157)$ is skewed to the right (data from Rossitti and Löfgren: Stroke 1993, 24: 371377). These data were omitted in the original publication $^{34}$.

Fig 6. Biological observables present apparently unpredictable oscillations. This figure shows time series on beat-to-beat basis $(a)$ and return maps $(b, c)$ of axial blood flow velocity $(\mathrm{Vm})$ in the middle cerebral artery registered with transcranial Doppler in a normal volunteer (male, aged 32). The signal oscillates considerably over time, and the physiological fluctuations of blood flow velocities may explain in part the variability of values recorded during routine transcranial Doppler diagnostic examinations. This variation over time is not just a random phenomenon, but rather the result of multiple feed back mechanisms involving variables such as the autoregulating mechanism of the cerebral circulation, the cardiac output, the beat-to-beat variations of the heart rate, the respiratory cycle, the hematocrit (blood viscosity), the plasma fibrinogen level (plasma viscosity), the arterial oxygen content, the arterial $\mathrm{CO} 2$ content, the metabolic activation of the brain tissue, the intracranial pressure and the cerebral vascular resistance ${ }^{39}$. Is it possible to describe such oscillations quantitatively? The answer is yes, to some extent, by using methods derived from deterministic chaos theory and fractal geometry. We may start by plotting the signal in two dimensional space, in the form of a return map or first-return scatter plot $(b, c)$. Return maps plot the value of the variable at time $n$ versus the value at time $n-1$. The diagonal line corresponds to the periodic points, occuring when $V m$ assumed the same value in heart cycles adjacent in time. The trajectories distributed nearer to the diagonal of the scatter plot correspond to the situation when measurements adjacent in time are near each other, while the points more distant to the diagonal correspond to trajectories departing more markedly from periodicity. The convergence or divergence of the trajectories relative to the periodical points may be described in terms of their fractal dimension and temporal correlation. For detail see the article by Rossitti and Stephensen ${ }^{39}$. Other methods are described inter alia in the books by West ${ }^{39}$ and in the collections of papers edited by Cvitanovic?, Hao Bai-Lin ${ }^{12}$ and Nonnenmacher et al. ${ }^{24}$.
A

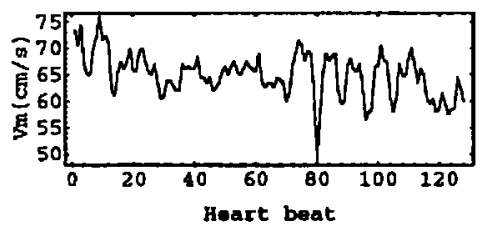

B

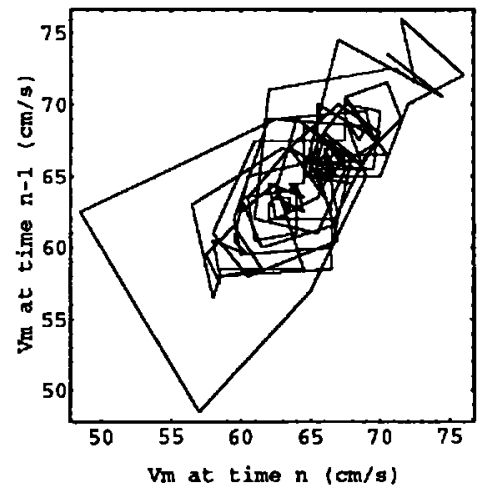

C

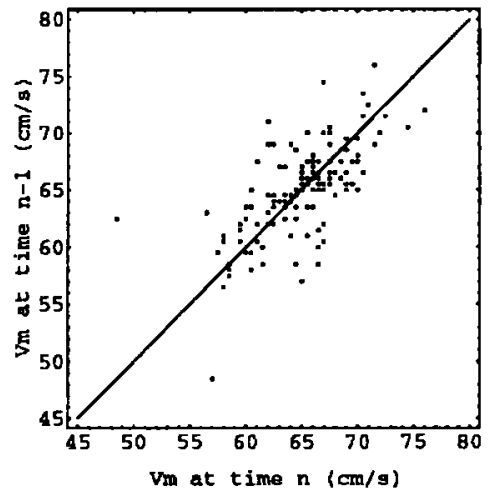


preliminary assumptions the endothelial cell contents are supposed to behave as a fluid (i.e. if it resists a strain by flow) or as a solid (if it resists a constant strain by deformation).

\section{SPATIAL CONSTRAINTS OF VASCULAR NETWORKS AND FRACTAL GEOMETRY}

The junction exponent just less than 3 is also compatible with the spatial constraints of arterial networks. Its has been suggested that arterial trees have a spatial fractal organization ${ }^{10,20}$, and that there is a relationship between their fractal complexity and their functional efficiency 8,18. A dichotomous fractal tree obeyng the junction rule $n=3$ on all branch generations would fill all three dimensions at the limit of null branch length, assuming a fixed vessel width/length ratio and that the length of each vessel is shorter than the summed lengths of its branches and larger than that of each individual branch. That means that in the case of such an arterial tree there would be no space available for other type of tissue, and even the vessels would have infinitely thin walls to obey this rule strictly ${ }^{20,32,34}$. The best arterial trees can achieve is to obey such a bifurcation rule over a limited range of branch generations with a diameter exponent of approximately three until the interpolation to narrower rami is interrupted by a cutoff at the length of the capilaries. Thus the general rule of junction exponents approximating 3 results in a nearly space filing arterial tree which is also energetically optimum.

\section{APPARENT INSTABILITY AT SHORT TIME INTERVALS}

The long term effect of blood flow-induced shear stress on the growth and adaptation of arterial networks is evident from its anatomy, or branching geometry. Such an observation is intriguing, because biological observables present apparently unpredictable oscillations over time ${ }^{38.39 .47}$. See Figure 6. Blood flow rate and shear stress are no exception, and the significance of such spontaneous irregular oscillations of blood flow rate and shear stress within each heart cycle and over longer time intervals on the endothelial cell response in the long term regulation of the vascular caliber is poorly understood. Some recent reports have got a glimpse on this problem. Studies in vitro suggest that the synthesis of endothelium-derived relaxing factor is influenced both by the frequency and amplitude of wall shear stress ${ }^{14,32}$, i.e. the pulse oscillations and the time-averaged shear stress have distinct influences on the endothelium. The instantaneous regulation of vessel tonus is flow- and shear strees- dependent. Smooth muscle cell membrane potentials in rabbitt pial arteries are repoted to stabilize at approximately the same level $(-58 \mathrm{mV})$ in response to flow, both in cells which are depolarized or hiperpolarized in relation to this level ${ }^{5}$. A study in vivo showed that the spontaneous oscillations of blood flow velocity (and wall shear stress) in the cerebral arteries follow fractal rules over time ${ }^{38.39}$. Fractal processes oscillate continuously due to internal feedback and are highly adaptive to external perturbations, which may lead to a long term stability which is evident even when considering simplified models assuming Poiseuille flow in arteries.

\section{REFERENCES}

1. Batjer H, Suss RA, Samson D. Intracranial arteriovenous malformations associated with aneurysms. Neurosurgery 1986, 18: 29-35.

2. Bevan JA, Bevan R (eds). The human brain circulation. London: Humana Press (Chapman \& Hall Medical), 1994.

3. Bevan JA, Joyce EH. Flow-induced resistance artery tone: balance between contrictor and dilator mechanisms. Am J Physiol 1990, 258: H663-H668.

4. Bevan JA, Laher I. Pressure and flow-dependent vascular tone. FASEB J 1991, 5: 2267-2273,

5. Bevan JA, Wellman GC. Intraluminal flow-initiated hyperpolarization and depolarization shift the membrane potential of arterial smooth muscle toward an intermendiate level. Circ Res 1993, 73: 1188-1192.

6. Brown N. A mathematical model for the formation of cerebral aneurysms. Stroke 1991, 22: 619-625.

7. Cvitanovic P (ed). Universality in Chaos. Ed 2. Bristol: Adam Higer, 1989.

8. Damiani G. Evolutionary meaning, functions and morphogenesis of branching structures in biology. In: Nonnenmacher TF, Losa, GA Weibel ER (eds). Fractals in biology and medicine. Basel: Birkhäuser, 1994, p 104-115. 
9. Fung YC, Liu SQ. Elementary mechanics of the endothelium of blood vessels. ASME J Biomech Eng 1993, 115: 1-12.

10. Griffith TM. Chaos and fractals in vascular biology. Vasc Med Rev 1994, 5: 161-182.

11. Griffith TM, Edwards DH. Basal EDRF activity helps to keep the geometrical configuration of arterial bifurcations close to the Murray optimum. J Theor Biol 1990, 146: 545-573.

12. Hao Bai-Lin (ed). Chaos II. Singapore: World Scientific, 1990.

13. Hassler W. Hemodynamic aspects of cerebral angiomas. Acta Neurochir (Wien) 1986, 37 (Suppl): 1-136.

14. Hutcheson, IR, Griffith TM. Release of endothelium-derived relaxing factor is modulated both by frequency and amplitude of pulsatile flow. Am J Physiol 1991, 261: H257-H262.

15. Kim C, Cervós-Navarro J, Kikuchi H. Alterations in cerebral vessels in experimental animals and their possible relationship to the development of aneurysms. Surg Neurol 1992, 38: 331-337.

16. La Barbera M. Principles of design of fluid transport systems in zoology. Science 1990, 249: 992-1000.

17. Lasjaunias $P$, Piske $R$, Terbrugge $K$, Wilinsky $R$. Cerebral arteriovenous malformations (CAVM) and associated arterial aneurysms (AA): analysis of 101 CAVM cases with 37 AA in 23 patients. Acta Neurochir (Wien) 1988, 91: 29-36.

18. Levèfre J. Teleonomical optimization of a fractal model of the pulmonary arterial bed. J Theor Biol 1983, 102: 225-248.

19. Liu YH, Ritman EL. Branching pattern of pulmonary arterial tree in anesthetized dogs. ASME J Biomech Eng 1986, 108: 289-293.

20. Mandelbrot BB. Trees and diameter exponent. In: The Fractal Geometry of Nature. New York: Freeman, 1983. p156-165.

21. Mayrovitz HN. An optimal flow-radius equation for microvessel non-newtonian blood flow. Microvasc Res 1987, 34: 380-384.

22. Mayrovitz HN, Roy J. Microvascular blood flow: evidence indicating a cubic dependence on arteriolar diameter. Am J Physiol 1983, 245: H1031-H1038.

23. Murray CD. The physiological principle of minimum work: I. The vascular system and cost of blood volume. Proc Nat Acad Sci USA 1926, 12: 207-214.

24. Murray CD. The physiological principle of minimum work applied to angle of branching of arteries. J Gen Physiol 1926, 9: 835-841.

25. Nerem RM.Hemodynamics and the vascular endothelium. ASME J Biomech Eng 1993, 115: 510-514.

26. Nonnenmacher TF, Losa, GA, Weibel ER (eds). Fractals in biology and medicine. Basel: Birkhäuser, 1994.

27. Norlén $G$. The cerebral circulation in supratentorial angiomas as studied by angiography before and after removal. In Proceedings of the 1st International Congress of Neurosurgery. Bruxelles: Les Editions "Acta Medica Belgica", 1957, p 217-222.

28. Okamoto $\mathrm{S}$, Handa $\mathrm{H}$, Hashimoto $\mathrm{N}$. Location of intracranial aneurysms asssociated with cerebral arteriovenous malformations: statistical analysis. Surg Neurol 1984, 22: 335-340.

29. Ostergaard JR. Risk factors in intracranial saccular aneurysms: aspects on the formation and rupture of aneurysms, and development of cerebral vasospasm. Acta Neurol Scand 1989, 80: 81-98.

30. Pile-Spellman JMD, Baker KF, Liszczak TM, Sandrew BB, Oot RF, Debrun G, Zervas NT, Taveras JM. High-flow angiopathy: cerebral blood vessel changes in experimental chronic arteriovenous fistula. Am J Neuroradiol 1986, 7: 811-815.

31. Rossitti S. Optimality principles and regulation of arterial caliber. Can J Physiol Pharmacol 1994, 72 (Suppl 4): 22.

32. Rossitti S, Frangos J, Girardi PR, Bevan J. Regulation of vascular tone. Can J Physiol Pharmacol (in press).

33. Rossitti S, Frisén L. Remodelling of the retinal arterioles in descending optic atrophy follows the principle of minimum work. Acta Physiol Scand 1994, 152: 333-340.

34. Rossitti S, Löfgren J. Vascular dimensions of the cerebral arteries follow the principle of minimum work. Stroke 1993, 24: 371-377.

35. Rossitti S, Löfgren J. Optmality principles and flow orderliness at the branching points of cerebral arteries. Stroke 1993, 24: 1029-1032.

36. Rossitti S, Lögren J. Optimality principles and the geometry of the cerebral arterial network. Biomech Sem 1993, 7: 21-26.

37. Rossitti S, Löfgren J. Why do the cerebral arteries develop saccular aneurysms? Upsala J Med Sci 1993, 52 (Suppl): 42.

38. Rossitti S, Löfgren J beskriven, Stephensen H. Blodflödeshastighetens tidsmässiga heterogenicitet i arteria cerebri media hos människa med fraktalanalys. Hygiea 1993, 102: 241.

39. Rossitti S, Stephensen H. Temporal heterogeneity of the blood flow velocity at the middle cerebral artery in the normal human characterized by fractal analysis. Acta Physiol Scand 1994, 151: 191-198. 
40. Sherman TF, On connecting large vessels to small: the meaning of Murray's law. J Gen Physiol 1981, 78: 431-453.

41. Smiesko V, Johnson PC. The arterial lumen is controlled by flow-related shear stress. News Physiol Sci 1993, 8: 34-38.

42. Stehbens WE. Pathology of the cerebral blood vessels. Saint Louis: C V Mosby 1972.

43. Stehbens WE. Etiology of intracranial berry aneurysms. J Neurosurg 1989, 70: 823-831.

44. Steiger HJ. Pathophysiology of development and rupture of cerebral aneurysms. Acta Neurochir (Wien) 1990, 48 (Suppl): 1-57.

45. Uylings HBM. Optimization of diameters and bifurcation angles in lung and vascular tree structures. Bull Math Biol 1977, 39: 509-520.

46. Vane JR. The endothelium: maestro of the blood circulation. Phi Trans R Soc Lond B 1994, 343: 225-246.

47. West BJ. Fractal physiology and chaos in medicine. Singapore: World Scientific, 1990.

48. Zamir M. Cost analysis of arterial branching in the cardiovascular systems of man and animals. J Theor Biol 1986, 120: 111-123. 